\title{
232 数種コナダニ類の分散に及はす温度の影響
}

松本克彦（東京女子医大、総合研究所）、山浦 常（東京女子医大、東洋医学研究所）

The effects of temperature on the dispersion in some species of grain mites.

Matsumoto Katsuhiko, Yamaura Hisashi

サトゥダニケナガコナダニの飼料からの分散は、低温側で、コオノホシカダニ は高温側で活発となる。イエニクダニ G.d.、オソアシブトコナダニ A.i.の分散 に及はす温度の影響を観察した。G.d.では、1日目はコオノホシカダニと同様 に高温側 $\left(35^{\circ} \mathrm{C}\right)$ の分散が活発であったが、2、3 日めで急激に減少し、2 $5^{\circ} \mathrm{C}$ の分散が最高となった。 3 日後の飼料内のダ二数は、 $25^{\circ} \mathrm{C}$ 以下のものに比心高温 側 $\left(30^{\circ} \mathrm{C} 、 35^{\circ} \mathrm{C}\right)$ のダ二数が減少し、ヒポプスの出現率の増加がみられた。特 に、35 Cで生存しているダニはヒポプスのみであった。A.i.も、やはり $35^{\circ} \mathrm{C} の$ 分散は、1 日目で最高であったが、以後急激に減少した。2 5 C以下の分散は、低 温でやや低い傾向を示したが顕著な差はみられなかった。G.d.、A.i.の分散は 高温側で活発となるが、高温に対する両種の抵抗性は他の種類より低かった。

233 札幌市近郊におけるススメバチ類の発生動態とその駆除、1995 年

高橋健一（北海道立衛生研究所）

outbreaks and control of hornets in Sapporo, 1995

Takahashi K.

1995 年に札㹸市に寄せられた八チ類に関する相談件数は1900件を越え過去最高であ つた。札谠市内で駆除されたスズメバチ要科のうち681例について種の同定を行った ところ、ケブカスズメバチが 240 件 (35\%) で最優占で、次いでキオビホオナガスズメ バチが184件（27\%）、コガタスズメバチが170件（25\%）で、これら3種で全体の87\%を 占めた。駆除件数は、広大な山林を後背地に抱える地域で多発した。駆除の対象とな つた㢼の営巣場所は、住宅のひさしなど人工物が $57 \%$ 、樹木が $40 \%$ 、その他（土中など） $3 \%$ あった。刺傷被害は 43 例で、キオビホオナガ 20 例、ケブカ 16 例、コガ夕5例、そ の他 2 例で、被害が発生した党巣場所は、樹木 23 例 (うちキオビ18例)、住宅などの 人工物 15 例 (うちケブカ11例)、その他 5 例であった。過去 7 年間の駆除状況を比較す ると、後背地に山林を抱える地域でのケブカを中心とした駆除件数の顕著な変化、お ょび、庭木を中心に営䉓するキオビホオナガ、コガタの駆除件数の增加がられた。 